\title{
BEDENSEL BÜTÜNLÜĞÜ İHLÂL EDİLEN EV KADINININ ÇALIŞMA GÜCÜNÜN KAYBI NEDENIYLE TAZMIN TALEBİ
}

\author{
Compensation Claim for Loss of Housewife's Livelihood \\ Due to Physical Incapacitation
}

Yrd. Doç. Dr. Fatma Tülay KARAKAŞ*

GIRISŞ, I.ALMAN HUKUKU'NDA, A.Genel Olarak Çalışma Gücü Kaybı, B.Ev Kadınının Zararı, II.İSVİÇRE HUKUKU'NDA, III.TÜRK HUKUKU'NDA, A.Öğreti, B.Yargısal Uygulama, SONUÇ

\section{ÖZET}

Bedensel bütünlüğü ihlâl edilen ev kadınının çalışma gücünün kaybı nedeniyle tazmin talebi, konuya salt fark kuramı açısından bakıldığında reddedilmelidir. Zira, fark kuramına göre, maddî bir zararın varlığından söz edilebilmesi için zarar görenin malvarlığında bir eksilme gerçekleşmiş olmalıdır. Bununla birlikte, Alman Hukuku'nda, Federal Mahkeme'nin 1962 yılında verdiği karardan bu yana ev kadınının tazmin talebi, hiçbir çekince gösterilmeksizin kabul edilmektedir. Gerekçe olarak, ev kadını tarafından yapılan işlerin piyasada bir karşılığının olduğu düşüncesinden hareket edilmekte ve böylelikle, ev işlerinde kullanılan çalışma gücü, malvarlığının kapsamına dahil edilmektedir. İsviçre Hukuku'nda da Federal Mahkeme, bedensel bütünlüğü ihlâl edilen ev kadınının tazmin talebini, ev işlerinin yapılması için ikame bir işgücünün istihdam edilip edilmediğinden bağımsız olarak ve geleneksel anlamı ile malvarlığında bir eksilme gerçekleşmemiş olmasına rağmen kabul etmektedir. Türk Hukuku'nda ise Yargıtay, bedensel bütünlüğü ihlâl edilen ev kadınının tazmin talebini, fark kuramı bağlamında malvarlığında bir eksilme olup

* Ufuk Üniversitesi Hukuk Fakültesi Medenî Hukuk Anabilim Dalı Öğretim Üyesi. 
olmadığını tartışmamakla birlikte kabul etmektedir. Aynı durum, emekliler açısından da geçerlidir. Burada da Yargıtay, halen bir işte çalışmayan ve ileride de çalışması mümkün olmayan emeklilerin tazmin talebini kabul ederek, çalışma gücünün kendisini (elde edilen karşılığı değil) bir malvarlığı değeri olarak kabul ettiğini göstermektedir.

Anahtar Kelimeler: Ev kadınının zararı, çalışma gücü, bedensel bütünlüğün ihlâli, fark kuramı, normatif zarar.

\section{ABSTRACT}

The compensation claim for the housewife's livelihood due to physical incapacitation should be rejected if it is only assessed through the theory of differentiation. According to the theory of differentiation, in order to demand for material damages, there has to be a tangible loss of assets, which a housewife's livelihood would be difficult to substantiate. However, according to a 1962 German federal court decision, a compensation claim for loss of housewife's livelihood is acceptable. The German decision reasoned that since the labor, a housewife performs, has a calculable market value, it should be included in the loss of assets. In Swiss Law, a federal court accepted compensation for loss of housewife livelihood without taking into account the value of any substitution used for the housework or whether there has been any actual loss. In Turkish Law, the Court of Appeals has accepted the concept of housewife's livelihood compensation while not considering whether there has been a loss in the assets in accordance with the theory of differentiation. The same is also applied to pensioners. In this case, the Court of Appeals pointed out that the livelihood itself, not the value of it, is accepted as an asset.

Keywords: Housewife damages, livelihood, the infringement of body integrity, the theory of differentiation, normative damage.

\section{GİRIŞ}

Türk Hukuku'nda Borçlar Kanunu'nun 46. maddesinde, “Cismanî bir zarara düçâr olan kimse külliyen veya kısmen çalışmaya muktedir olamamasından ve ileride iktisaden maruz kalacağı mahrumiyetten tevellüt eden zarar ve ziyanını ve bütün masraflarını isteyebilir" hükmü yer almaktadır.

Yasa koyucu, bu hükümde, çalışamamaktan kaynaklanan zararın talep edilebilmesi için, zarar görenin zarar verici olay gerçekleşmeden önce kazanç getirici bir işte çalışıyor olması gerektiğini öngörmemiştir. Dolayısıyla hüküm tek başına ele alındığında, kişi ister kazanç getirici bir işte çalışıyor olsun, isterse olmasın çalışma gücünü kısmen veya tamamen kaybetmişse tazmin talebinde bulunabilecektir. Bunun için tek koşul, kişinin 
zararın gerçekleştiği anda çalışma gücüne sahip olması veya ileride sahip olabilecek (örn. çocuklar için) olmasıdır.

Ancak konu, maddî zarar ve maddî zararın tazmini ile ilgili esaslar ile birlikte değerlendirildiğinde tazmin edilebilirliğin sorunsuz olmadığı görülmektedir. Zira, Borçlar Kanunu'nda açıça ifade edilmemiş olmakla birlikte yarg1 uygulamasında ${ }^{1}$ ve öğretide ${ }^{2}$ oybirliği ile kabul edildiği üzere, maddî zarar, "fark kurami" esas alınarak belirlenmektedir.

Fark kuramına göre zarar, zarar verici olay gerçekleşmeseydi malvarlığının arzedeceği durum ile (varsayımsal malvarlı̆̆ 1 ), zarar verici olay gerçekleştikten sonra malvarlığının arzettiği durum (gerçek malvarlığı) arasındaki farktır. Başka bir deyişle, maddî bir zararın varlığından söz edilebilmesi için zarar görenin malvarlığında bir eksilmenin gerçekleşmiş olması aranacaktır.

Bedensel bütünlügün ihlâli nedeniyle çalışma gücü kaybedildiğinde de aynı durum geçerlidir ve burada da tazminata karar verebilmek için kişinin malvarlığında bir eksilme aranmalıdır. Ancak bu koşul, bedensel bütünlüğü ihlâl edilen kişi, ev kadını, emekli, işsiz veya öğrenci olduğunda, bu kişilerin tazmin talebinden yoksun kalması sonucunu doğurmakta ve BK'nun 46. maddesinde yer alan "çalışamamaktan kaynaklanan zarar"dan ne anlaşılması gerektiğini tartışmaya açık hale getirmektedir ${ }^{3}$.

Burada sorun, öncelikle, yasa hükmünde koruma altına alınan değerin ne olduğu ile ilgilidir. Eğer BK m. 46'daki düzenlemede, "çalışma

1 Yarg. 4. HD'nin 12.1.1981 T. ve E. 1981/13394, K. 1982/274 say1l karar1: “... zarar, diğer bir deyimle malvarlığındaki eksilme, gerek Alman ve gerekse Türk-İsviçre Hukukları'ndaki baskın görüsse göre malvarlığının zarar verici olaydan sonraki durumu ile bu olay meydana gelmese idi mevcut olacak durumu arasındaki farktan ibarettir. Hukuk literatüründe fark teorisi adı ile anılan bu görüş, zararı matematiksel açıdan ele almakta ve soyut biçimde değerlendirmektedir..." (YKD, 1982, S. 5, s. 645 vd.). Ayn1 sekilde bkz.: Yarg. 4. HD 12.12.1979 T., E. 9779, K. 13899 (Uygur, T.: Açıklamal1-İçtihatlı Borçlar Kanunu, Sorumluluk ve Tazminat Hukuku, C. II, s. 1384-1385); Yarg. 4. HD 12.1.1982 T., E. 13394, K. 274 (Uygur, s. 1375 vd.); Yarg. 4. HD 28.2.1984 T., E. 668, K. 1950 (Uygur, s. 1402-1403); Yarg. 4. HD 19.11.1987 T., E. 6597, K. 8462 (Uygur, s. 1377); YHGK 3.10.1984 T., E. 4-857, K. 783 (Uygur, s. 1387).

2 Tandoğan, H.: Türk Mes'uliyet Hukuku, Ankara 1961, s. 64; von Tuhr, A.: Borçlar Hukukunun Umumî Kısmı (Cev.: Edege, C.), C. 1-2, Ankara 1983, s. 77, 107; Deschenaux, H./Tercier, P.: Sorumluluk Hukuku (Cev. Ozdemir, S.), Ankara 1983, s. 20; Tunçoma $\breve{g}$, K. Borçlar Hukuku, C. I, Genel Hükümler, İstanbul 1972, s. 286; Tekinay, S. S./Akman, S./Burcuoğlu, H./Altop, A.: Borçlar Hukuku Genel Hükümler, 7. B., İstanbul 1993, s. 548; Eren, F.: Borçlar Hukuku Genel Hükümler, 8. B., İstanbul 2003, s. 477; Oğuzman, K./Öz, T.: Borçlar Hukuku Genel Hükümler, 4. B., İstanbul 2005, s. 514.

3 Ev kadınının ölümü halinde gündeme gelen destekten yoksun kalma tazminatında ise, konu, bütünüyle sorunsuzdur. Gelir getirici bir işte çalışmayan ev kadınının ölümü halinde, kocanın ve çocukların destekten yoksun kalma tazminatı talep edebileceği kabul edilmektedir. Zira, destek, tazminat talebinde bulunana, fiilen ve düzenli olarak bakan veya ileride bakması kuvvetle muhtemel olan kimsedir. Ayrıntılı bilgi için bkz.: Gökyayla, K. E.: Destekten Yoksun Kalma Tazminatı, Ankara 2004, s. 98 ve s. 122 vd. 
gücünün", malvarlıksal bir değer olarak korunduğu söylenebilirse, çalışma gücüne sahip olan herkesin tazmin talebinde bulunabileceği kabul edilecektir. Eğer yasa hükmünde çalışma gücünün kendisinin değil de çalışma gücü karşılığında hâlihazırda elde edilen veya elde edilmesi olası gelirin koruma altına alındığı kabul edilirse, kişinin tazmin talebinde bulunabilmesi için, gelir getirici bir işte çalışıyor olması veya ileride çalışabilecek olması aranacaktır.

$\mathrm{Bu}$ sorun, bedensel bütünlüğü ihlâl edilen kişi ev kadını olduğunda Alman ve İsviçre Hukuku'nda belirli bir sonuca bağlanmış görünmektedir. Zira, ev kadınının tazmin talebi, emekli, işsiz veya öğrenci ile kıyaslandığında farklı bir özellik sergilemektedir. Ev kadını, evdeki çalışması karşıllı̆̆ında herhangi bir ücret almamakla birlikte, ev işleri başka bir kişi tarafından yapıldığında bu kişi ücrete hak kazanmakta, dolayısıyla ev işlerinin yapılmasının piyasada ölçülebilen bir değeri bulunmaktadır.

$\mathrm{Bu}$ çalışma, konunun Alman İsviçre ve Türk Hukuku'nda nasıl ele alındığını incelemekte ve Türk Hukuku'nda benimsenebilecek çözüm ile ilgili önerilerde bulunmaktadır.

\section{ALMAN HUKUKU'NDA}

\section{A. Genel Olarak Çalışma Gücü Kaybı}

Alman Hukuku'nda Federal Mahkeme, "çalışma gücünü”, bir malvarlığı değeri olarak kabul etmemektedir ${ }^{4}$. Bu nedenle Federal Mahkeme, çalışma gücünün geçici olarak veya sürekli, tamamen veya kısmen kaybı halinde ortaya çıkan zararı, çalışma gücünün piyasada objektif olarak belirlenen parasal değerine göre değil, zarar görenin somut olarak bir kazanç kaybına uğrayıp uğramadığına veya gelecekte uğrayıp uğramayacağına göre hesaplamaktadır. Dolayısıyla çalışma gücü kaybı, çalışma yeteneğinin kişiye bağlı (sübjektif) niteliği nedeniyle "iş yapabilirlik değeri" değil, "karşıllk (ücret)" esaslıdır ${ }^{5}$. Federal Mahkeme'nin bu görüşü, öğretinin büyük çoğunluğu tarafından da kabul edilmektedir ${ }^{6}$.

${ }^{4}$ Buradaki yargı uygulaması ile kastedilen adlî yargıdır. Alman Hukuku'nda Federal İş Mahkemesi, Alman Federal Mahkemesi tarafindan kabul edilen normatif zarar kavramına dayanarak çalışma gücünü bir malvarlığı değeri olarak kabul etmektedir [Bkz. BAG 24.4.1970, JZ 1971, 380 (381)].

5 Magnus, U.: Schaden und Ersatz, Tübingen 1987, s. 240.

6 Larenz, K.: Lehrbuch des Schuldrechts, Bd. I, Allgemeiner Teil, 14. Aufl., München 1987, s. 507; Stoll, H.: Begriff und Grenzen des Vermögensschadens, Karlsruhe 1973, s. 24; Erman/Kuckuk, Bürgerliches Gesetzbuch, 11. Aufl., Münster-Köln 2004, § 249 Rz. 53; Soergel, H. T./Mertens, H. J.: Bürgerliches Gesetzbuch, Stuttgart 1990, Vor § 249 Rz. 11 Palandt, O./Heinrichs, H.: Bürgerliches Gesetzbuch, 62. Aufl., München 2003, Vorb. v. § 249 Rz. 36; Medicus, D.: Schuldrecht, Allgemeiner Teil, 8. Aufl., München 1995, s 303. İşgücünün bir malvarlığı değeri olup olmadığı ile ilgili tartışmalar için bkz.: Brinker, J.: Die Dogmatik zum Vermögensschadensersatz, Berlin 1982, s. $120 \mathrm{vd.}$ 
Alman Hukuku'nda, azınlıkta kalan görüş ise çalışma gücünün bir malvarlığı değeri olduğunu kabul etmektedir. Bu görüşün taraftarlarından Grunsky'ye göre, "günümüzde çalıșma gücü insanların büyük bir bölümü için en önemli gelir kaynağıdır ve bu nedenle de malvarlığının esaslı unsurlarından biri olarak kabul edilmelidir". Dolayısıyla çalışma gücü ihlâl edildiğinde tazmin talebi, bu gücün kazanç getirici bir işte kullanılıp kullanılmadığından bağımsız olarak ele alınmalı ve kazanç getirici bir işte kullanılmasa dahi tazminat sağlanmalıdır ${ }^{7}$.

Grunsky, çalışma gücünün kendiliğinden bir malvarlığı değerine sahip olduğu tezini verdiği şu örnekle gerekçelendirmektedir: "Nasıl ki, mülkiyet hakkı ihlâl edildiğinde, zarar görenin tazminat talebi, mülkiyetin konusunu oluşturan eşyanın malik tarafindan satılmak istenip istenmediğinden bağımsız olarak kabul ediliyorsa, çalışma gücü ihlâl edildiğinde de tazmin talebi, zarar görenin çalışma gücünü para kazanmak için kullanmak isteyip istemediğinden bağımsız olarak kabul edilmelidir"”.

Alman Hukuku'nda Magnus da, gelir getirici bir işte kullanılmasa dahi çalışma gücünün kaybı halinde tazmin talebinin kabul edilmesi gerektiğini ifade etmekte ancak buradaki tazminatın maddî değil, İngiliz ve Fransız Hukuku'nda olduğu gibi manevî tazminat olması gerektiğini söylemektedir'.

\section{B. Ev Kadınının Zararı}

Alman Hukuku'nda, Federal Mahkeme'nin 1962 y1lında verdiği karardan ${ }^{10}$ bu yana bedensel bütünlügü ihlâl edilen ev kadınının çalışma gücünü kaybetmesi nedeniyle ortaya çıan zararı hiçbir çekince gösterilmeksizin kabul edilmektedir.

Federal Mahkeme tarafından benimsenen bu görüşün temelleri Almanya'daki aile hukukunun gelişimininde bulunmaktadır.

Alman Hukuku'nda "Cinsler Arasında Eşit Haklar Yasası" kabul edilinceye kadar, koca, kadının ev işlerini yapması konusunda yasal bir talep hakkına sahipti. Bu nedenle, ev kadınının bedensel bütünlüğg̈, ev işlerini

7 Grunsky, W.: Aktuelle Probleme zum Begriff des Vermögensschadens, Berlin-Zürich 1968, s. 87. Ayrica bkz.: Grunsky, W.: Münchener Kommentar zum Bürgerlichen Gesetzbuch, München 1994, Vor § 249 Rz. 24.

8 MüKo/Grunsky, Rz. 24.

9 Magnus, s. 260, ayrica bkz. s. 334. Magnus, zarar ve zararın tazmini ile ilgili Fransiz, İngiliz, Amerikan ve Alman hukuk düzenlerini karşılaştırmalı olarak incelediği kapsamlı çalışmasında çalışma gücünün kaybı ile ilgili sorunlara da geniş bir yer ayırmıştır. Yazar, somut anlamda parasal bir kayıp gerçekleşmese dahi Fransız, Ingiliz ve Amerikan Hukuku'nda bu nedenle tazmin talebinin kabul edildiğini, ancak İngiltere ve Fransa'da çalışma gücü, şahısvarlığı değeri olarak görüldüğü için manevî tazminatın, Amerika'da ise malvarlığı değeri olarak görüldüğü için maddî tazminatın sağlandığını ifade etmektedir (Magnus, s. 259-260).

${ }^{10} \mathrm{BGH}$ 25.9.1962, BGHZ 38, 55. 
yapamayacak şekilde ihlâl edildiğinde, koca, zarar gören olarak kabul ediliyor ve kocaya tazminat ödenmesine karar veriliyordu ${ }^{11}$.

1958 yılında Eşit Haklar Yasası'nın yürürlüğe girmesinden sonra, ev kadınının çalışma gücünün, kocanın malvarlığının bir bölümü olarak değerlendirilmesine son verilmiş ve ev kadınının bağımsız tazmin talebi, somut olarak malvarlıksal bir kayıp ortaya çıkmamasına rağmen kabul edilmiştir $^{12}$. Ev işlerinin erkek tarafından yapılıyor olması halinde ve Yaşam Ortaklığ1 Yasası'na göre tescil edilmiş birlikteliklerde de aynı sonuç geçerlidir $^{13}$. Yalnız yaşayan bir kadın ve erkek de bedensel bütünlüğünün ihlâl edilmiş olması nedeniyle ev işlerini yapamıyorsa tazmin talebinde bulunabilir $^{14}$.

Federal Mahkeme, bedensel bütünlüğü ihlâl edilen ev kadının zararını "normatif zarar" kuramı ile gerekçelendirmektedir ${ }^{15}$. Bu kurama göre, geleneksel zarar kuramı (fark kuramı) anlamında malvarlığında bir eksilme olmasa dahi, bazı kayıplar, hukuksal bir değer yargısı ile yani normatif bir yöntemle zarar olarak kabul edilmekte ${ }^{16}$ ve tazmin yükümlülüğ̈̈nün kapsamına dahil edilmektedir. Ev kadınının zararında da, ev işleri başka bir kişi tarafından yapılmış olsaydı, bu kişiye bir ücret ödenmesi gerekeceği, dolayısıyla ev kadını tarafından yapılan işlerin piyasada bir karşılığının olduğu düşüncesinden hareket edilerek, ev işlerinde kullanılan çalışma gücü malvarlığının kapsamına dahil edilmiştir. Nitekim, normatif zarar kavramı da ilk kez, ev kadınının bağımsız tazmin talebini kabul eden Federal Mahkeme kararında kullanılmıştır ${ }^{17}$.

Alman Federal Mahkemesi, ev kadının ev işlerini yapamaması nedeniyle ortaya çıan zararı ile ilgili olarak tazminata karar verebilmek için, ev işlerinin zarar verici olaydan önce fiilen yapılıyor olması koşulunu $\operatorname{aramaktadı1}^{18}$. Ancak öğretide Mahkeme'nin bu tutumu, malvarlı̆ğ zararının,

${ }^{11}$ Medicus, D.: JuS 1979, s. 233; Medicus, Schuldrecht, s. 302; Erman/Schiemann, G.: Bürgerliches Gesetzbuch, 11. Aufl., Münster-Köln 2004, § 843 Rz. 5; Nomer, H.: Haksız Fiil Sorumluluğunda Maddî Tazminatın Belirlenmesi, İstanbul 1996, s. 27.

12 Magnus, s. 241-242; Medicus, Schuldrecht, s. 302; Nomer, s. 28. Bu konuda ayrıntılı bilgi için bkz. Maier, G.: Schadensersatz bei Tötung oder Verletzung der im Haushalt tätigen oder im Beruf oder Geschäft des Mannes mitarbeitenden Ehefrau, Berlin 1976.

13 Palandt/Heinrichs, Vorb. v. § 249 Rz. 42; Lange, H./Schiemann, G.: Schadensersatz, 3. Aufl., Tübingen 2003, s. 325.

${ }_{15}^{14}$ Lange/Schiemann, s. 324. Ayrica bkz.: BGH NJW-RR 1992, 792; KG VersR 1982, 978.

15 Erman/Schiemann, § 843 Rz. 5; Palandt/Heinrichs, Vorb. v. \$249 Rz. 42; Grunsky, Rz. 24; Jauernig, O./ Teichmann, A.: Bürgerliches Gesetzbuch, München 1997, Vor $\$ \S 249$ 253 Rz. 9; Medicus, Schuldrecht, s. 302; Schiemann, G.: Argumente und Prinzipien bei der Fortbildung des Schadensrechts, München 1981, s. 69 vd.

${ }^{16}$ Lange/Schiemann, s. 37. Normatif zarar kuramı konusunda ayrıca bkz.: Karakaş, F. T.: Eleştirel Bakış Açısıyla Normatif Zarar Kuramı, Ankara 2004, s. 44 vd. (yayımlanmamış doktora tezi).

${ }^{17}$ BGHZ 50, 304 vd.

${ }^{18}$ BGH 5.5.1970, BGHZ 54, 45; BGH 7.5.1974, NJW 1974, 1651. 
sadece fiilî olarak yürütülen ev işlerinin yapılamamasında ortaya çıkmayacağı, gelecekte yapılması planlanan ev işleri bakımından da aynı kaybın gerçekleşebileceği gerekçesiyle eleştirilmektedir ${ }^{19}$.

Tazminat, ailedeki bireylerin sayısına göre belirlenmekte ve ev işlerini görenler için kullanılan tarife de göz önünde bulundurulmaktadır ${ }^{20}$.

\section{II. İSVIÇRE HUKUKU'NDA}

İsviçre Hukuku'nda da Alman Hukuku'nda olduğu gibi çalışma gücünün kendiliğinden bir malvarlığı değerine sahip olduğu düşüncesi reddedilmekte ve soyut kayıpların değil, somut olarak ortaya çıkan kayıpların (fark kuramı) tazmin edilmesi gerektiği düşüncesi benimsenmektedir ${ }^{21}$. Bununla birlikte İsviçre Hukuku'nda da Federal Mahkeme, bedensel bütünlüğü ihlâl edilen ev kadınının tazmin talebini, ev işlerinin yapılması için ikame bir işgücünün istihdam edilip edilmediğinden bağımsız olarak ve geleneksel anlamı ile malvarlığında bir eksilme gerçekleşmemiş olmasına rağmen kabul etmektedir.

İsviçre Federal Mahkemesi de gerekçe olarak normatif zarar kuramına dayanmaktadır. Federal Mahkemeye göre, "tazminat yükümlüsü sadece ev işleri için yapılan somut harcamaları değil, -ikame bir işgücünün istihdam edilip edilmediğinden bağımsız olarak- ev işlerinin yapılamaması nedeniyle ortaya çıkan ekonomik değer kaybını, yani normatif zararı da tazmin etmelidir. Bunun için malvarlığında bir eksilmenin gerçekleşmiş olması gerekmez"22.

İsviçre Hukuku'nda öğreti, bedensel bütünlüğü ihlâl edilen ev kadınının ev işlerini yapamaması nedeniyle ortaya çıkan zararının tazmini konusundaki Federal Mahkeme'nin bu tutumunu çoğunlukla ${ }^{23}$ kabul etmekte ise de, Alman Hukuku'nun aksine, tam bir görüş birliği bulunmamaktadır. Örneğin, Honsell, Federal Mahkeme'nin sergilediği bu tutumu, tazminat

${ }^{19}$ Magnus, s. 244. Magnus'a göre, zarar gören, zarar verici olaydan önce üstlenmediği ev işlerini gelecekte yapmayı düşünüyorsa, ancak bu arada zarar verici olay gerçekleşmişse, burada da bir kayıp söz konusudur (Magnus, s. 244).

${ }^{20}$ BGH 8.6.1982, VersR 1982, 874

${ }^{21}$ Honsell, H.: Schweizerisches Haftpflichtrecht, 3. Aufl., Zürich 2000, s. 89; Roberto, V.: Schadensrecht, Basel-Frankfurt a. M. 1997, s. 231-232; Roberto, V.: Schweizerisches Haftpflichtrecht, Zürich 2002, s. 192, 211.

22 BGE 99 II 221 vd.; BGE 108 II 437 vd.; BGE 113 II 350 vd.; BGE 127 III 405 vd.

${ }^{23}$ Roberto, Schadensrecht, s. 212 vd.; Roberto, Haftpflichtrecht, s. 211; Schwenzer, I.: Schweizerisches Obligationenrecht, Allgemeiner Teil, 2. Aufl., Bern 2000, s. 67; Gauch, P.: Grenzüberschreitungen im privaten Schadensrecht, Richterliche Rechtsfortbildung in Theorie und Praxis, Festschrift für Hans Peter Walter, Bern 2005, s. 296; Merz, H. Schweizerisches Privatrecht, Bd. VI, Obligationenrecht, Allgemeiner Teil, Teilbd. 1, BaselFrankfurt a. M. 1984, s. 201; Rev, H.: Ausservertragliches Haftpflichtrecht, Zürich 1995, s. 49; Oftinger, K.: Schweizerisches Haftpflichtrecht, Bd. I, Allgemeiner Teil, 4. Aufl., Zürich 1975 , s. 207. 
hukukundaki zenginleşme yasağına aykırı bularak eleştirmekte ve Federal Mahkeme'nin benzer olaylarda (serbest meslek sahipleri yönünden) tazmin talebini reddederek farklı davrandığını ifade etmektedir ${ }^{24}$.

Brehm ise burada, bir yardımcı güç istihdam edilse bile tazmin edilebilir bir zararın bulunmadığını söylemektedir. Yazara göre, ev kadını çalışması karşıllı̆ında bir ücret elde etmediği için burada yoksun kalınan bir kazanç (lucrum cessans) bulunmamaktadır. Yazar, ev kadınının ev işlerini yapamadığı süre için bir yardımcı güç istihdam edildiğinde ise, bir fiilî zararın (damnum emergens) bulunduğunu; ancak bu zararın sadece ev kadınının şahsında değil, aile fertlerinin tümünün şahsında ortaya çıtığını; zira istihdam edilen ikame gücün aile fertlerinin tümüne hizmet ettiğini söylemektedir. Yazara göre, burada zarar, aile fertlerinin tümü tarafindan paylaşılmaktadır ve ev kadını sadece kendisine düşen oran üzerinde tazmin talebinde bulunabilir. Diğer aile fertlerinin şahsında ortaya çıkan zarar ise tazmini mümkün olmayan bir yansıma zarardır. Brehm, Federal Mahkeme'nin, zararı değil, Alman Hukuku'ndan normatif zararı örnek alarak iş yapabilirliği, yani "ekonomik değer kaybını" tazmin ettiğini, bu "zararsız tazminat"ın İsviçre tazminat hukukuna yabancı olduğunu söylemektedir ${ }^{25}$.

İsviçre Federal Mahkemesi, tazminatın belirlenmesinde somut ve soyut metod arasında ortalama bir yol seçmiştir ${ }^{26}$. Federal Mahkeme'ye göre tazmin yükümlüsü somut olarak ortaya çıkan zararı, yani ailedeki bireylerin sayısı ve ailenin koşulları dikkate alınarak o bölgede bir yardımcı güç için ödenebilecek somut ücreti (masraf metodu) değil, somut olarak yapılan harcamaların hareket noktası olarak alındığı istatiksel günlük zaman ihtiyaç değerlerine dayalı soyut zararı tazmin etmelidir ${ }^{27}$.

Bugün İsviçre Hukuku'nda, zararın soyut olarak belirlenmesinde Federal İstatistik Dairesi tarafından 1997 yılında yayınlanan İsviçre İşgücü İstatistiği (SAKE 97) dikkate alınmaktadır ${ }^{28}$.

${ }^{24}$ Honsell, s. 93.

${ }^{25}$ Brehm, R.: Berner Kommentar, Schweizerisches Zivilgesetzbuch, Das Obligationenrecht, Bd. VI, 1. Abt. Allgemeine Bestimmungen, 3. Teilbd., 1. Unterteilbd. Die Entstehung durch unerlaubte Handlungen, Kommentar zu Art. 41-61 OR, 2. Aufl., Bern 1998, s. 313.

${ }_{27}^{26}$ BGE 108 II 437 vd.; Roberto, Haftpflichtrecht, s. 212.

27 Roberto, Haftpflichtrecht, s. 212. Ayrica bkz.: Brehm, s. 313-314; Keller, A.: Haftpflicht im Privatrecht, Bd. II, 2. Aufl., Bern 1998, s. 63 vd.

${ }^{28}$ Honsell, s. 92. 


\section{TÜRK HUKUKU'NDA}

\section{A. Öğreti}

Alman ve İsviçre Hukuku'nun aksine Türk Hukuku'nda bedensel bütünlüğü ihlâl edilen ev kadınının ev işlerini yapamaması nedeniyle ortaya çıkan zararı, üzerinde çok fazla durulmuş bir konu değildir.

Hukukumuzda, Oğuzman/Öz, ev kadınının, kocasını hizmetçi tutmaktan kurtarmak suretiyle aile bütçesine katkıda bulunduğunu, ev kadınının vücut bütünlüğü ihlâl edildiğinde bu katkıdan mahrum kalınacağını ve bunun da bir kazanç mahrumiyeti sayılacağını söylemektedir ${ }^{29}$. Aşçıoğlu, zarar görenin gelir getirici bir işte çalışmayan ev kadını olması durumunda, ev kadınının yaptığ 1 ev işlerine göre, ailenin sosyal ve ekonomik durumu gözetilerek tahmini bir gelirin kabul edilebileceğini ifade etmektedir ${ }^{30}$. Nomer, evli kadının, yaralanmaya ve bu sebeple doğan işgöremezlik haline rağmen, ek bir masraf yapmaması halinde, malvarlığında eksilme meydana gelmeyeceğinden, zarara uğradığından söz edilemeyeceği görüşündedir ${ }^{31}$.

Öğretide konu ile ilgili olarak ileri sürülen sınırlı sayıdaki bu görüşlerin dışında, tazmin edilebilirliğin mümkün olup olmayacağının değerlendirilebilmesi için, genel olarak çalışma gücünün kaybı ile ilgili görüşlerin de ele alınmasında yarar bulunmaktadır.

Öğretide, çalışma gücünün azalması ve kaybında aslolanın kazanç kaybı veya azalması değil, kazanma (çalışma) gücünün kaybı veya azalması olduğu ifade edilmektedir ${ }^{32}$. Bu ifadeden hareketle zararın tazmini için malvarlığında bir eksilmenin şart olmadığı gibi bir sonuç çıkarılabilirse de esasen burada söylenmek istenen çalışma gücünün kendisinin bir malvarlığg 1 değerine sahip olduğu hususu değildir. Burada sözü edilen çalışma gücünün sürekli kaybı halinde gelecekteki kazanç olanaklarının belirlenmesi ile ilgilidir. Zira, bu halde geleceğe yönelik varsayımsal bir hesaplama yapılmakta ve kişinin gelecekte elde edebileceği olası kazanç

\footnotetext{
${ }_{30}^{29}$ Oğuzman/Öz, s. 559.

${ }^{30}$ Aşçıoğlu, Ç.: Trafik Kazalarında Hukukî Sorumluluk ve Tazminat Davaları, Ankara 1989, s. 174.

${ }^{31}$ Nomer, s. 29.

${ }^{32}$ Eren, s. 713. Benzer şekilde Tekinay/Akman/Burcuoğlu/Altop, s. 604; Tandoğan, s. 285. Oğuzman/Öz, Borçlar Kanunu'nun 46. maddesindeki zararın kapsamına, davacının tazminata hüküm verileceği tarihe kadar olan kazanç mahrumiyeti girdiği gibi, çalıșma gücünün tamamen kaybının veya azalmasının (kısmî kaybının) gelecekte yol açacağı kazanç mahrumiyetinin de gireceğini ifade etmektedir (Ö̆uzman/Öz, s. 559). Deschenaux/Tercier, Borçlar Kanunu'nun 46. maddesindeki müstakbel ekonomik kaybın, bedensel bütünlüğe yapılan saldırı dolayısıyla kazanç olanaklarının kaybı veya azalması olduğunu söylemektedir (Deschenaux/Tercier, s. 189).
} 
araştırılmaktadır $^{33}$. Örneğin bir çocuğun veya çalışmak istediği halde zarar verici olayın gerçekleştiği anda işsiz olan bir kimsenin gelecekteki kazanç olanaklarının araştırılmasında olduğu gibi. Oysa, bedensel bütünlüğü ihlâl edilen kişi ev kadını olduğunda ev kadınının hâlihazırda bir geliri olmadığı gibi, ileride de gelir elde etme olanağ 1 bulunmamaktadır. Bedensel bütünlüğü ihlâl edilen kişi emekli olduğunda da aynı sonuç geçerlidir. Öğrenci ve işsizler bakımından ise, konu, çalışma gücünün geçici olarak kaybedilmesi halinde önem taşımaktadır.

Öğrenci ve işsizler söz konusu olduğunda, çalışma gücünün sürekli $k a y b$ c halinde gelecekteki kazanç olanakları bakımından varsayımsal bir hesaplama yapılabilir ve böylelikle zarar belirlenebilir. Buradaki zarar, gelecekte elde edilmesi mümkün olan yoksun kalınan kazançtır. Ancak bu kişiler çalışma güçlerini geçici olarak kaybettiklerinde, zarar verici olayın gerçekleştiği tarihte gelir getirici bir işte çalışmadıklarından hâlihazırda yoksun kaldıkları bir kazançları da bulunmayacaktır.

\section{B. Yargisal Uygulama}

Bedensel bütünlüğü ihlal edilen ev kadınının zararı, yarg1 uygulamasında da üzerinde çok fazla tartışılan konulardan biri değildir. Bununla birlikte konunun yargı uygulamasında hiç yeri olmadığı da söylenemez. Özellikle, aşağıdaki kararlar konuya 1şık tutacak niteliktedir.

Yargıtay 15. HD, 20 Ekim 1975 tarihli kararı ${ }^{34}$ ile, bedensel bütünlüğü ihlâl edilen ev kadınının, "normal yaşama süresince, ev işlerini ve hizmetlerini yürütürken, beden gücündeki eksilme nedeniyle fazla efor sarf etmesi karşılı̆̆ 1 olarak maddî tazminat ödetilmesine hak kazandığını" kabul etmiştir.

Yargıtay 11. HD, 18 Ocak 1979 tarihli karar1 ${ }^{35}$ ile, bedensel bütünlüğü ihlâl edilen ve bu nedenle çalışma gücünü geçici olarak kaybeden ev kadınının tazmin talebini reddeden yerel mahkeme kararını, "ev kadınının sosyal durumu, ev işlerindeki beceri derecesi ve yükümlü bulunduğu aile efradı sayısı dikkate alınarak, bu işlerin bir başkası tarafından yapılması halinde ne gibi bir ücret ödeneceğinin bilirkişi marifetiyle tespit edilmesi ve ortaya çıkacak sonuca göre karar verilmesi gerektiği”" gerekçesiyle bozmuştur.

\footnotetext{
${ }^{33}$ v. Tuhr, s. 367; Feyzioğlu, F. N.: Borçlar Hukuku Genel Hükümler, C. I, 2. B., İstanbul 1976, s. 598; Ŏguzman/Öz, s. 559; Tunçomağ, s. 301; Tekinay/Akman/Burcuoğlu/Altop, s. 605; Tandoğan, s. 286; Eren, s. 713.

${ }^{34}$ Yarg. 15. HD 20.10.1975 T., E. 3787, K. 4103 (YKD, 1976, S. 6, s. 879).

${ }^{35}$ Yarg. 11. HD 18.01.1979 T., E. 1978/5550, K. 1979/93 [http://www.kazanci.com.tr (E. T.: 09.05.2006)]
} 
Yargıtay 19. HD, 3 Ekim 1995 tarihli karar1 ${ }^{36}$ ile, "davacının emeklilik yaşından başlayarak yaşam süresi sonuna kadar geçecek pasif dönem içinde ev kadını olarak yaşamını sürdüreceği ve sakatlığı oranında fazla güç harcayacağı kabul edilerek asgarî ücret baz alınmak suretiyle pasif dönem zararının uzman bilirkişiye hesaplatılması gerekeceğine" hükmetmiştir.

Yargitay 11. HD, 27 Haziran 1996 tarihli karari $^{37}$ ile, trafik kazası sonucu yaralanan ev kadınının, bu yaralanma nedeniyle talep ettiği tazminatın, ev kadınının ölüm tarihine kadar çalışacağı kabul edilerek hesaplanması gerektiğine hükmetmiştir.

Yargitay 4. HD, 28 Aralık 1998 tarihli kararı $^{38}$ ile, trafik kazası nedeniyle \% 34 oranında işgücü kaybına uğrayan ve çalıştığına ilişkin delil bulunmayan 68 yaşındaki kişinin işgücü kaybına yönelik isteğini reddeden yerel mahkeme kararını, "davacının yaşadığı sürece malûliyeti nedeniyle daha fazla güç (efor) sarf edeceği dikkate alınarak yaşı ve yaşam tarzına göre ne miktar gelir elde edebileceğinin belirlenmesi ve bu belirlemeye göre davacının çalışma gücü kaybı zararının hesaplanması gerektiği” gerekçesi ile bozmuştur.

Görüldüğü gibi Yargıtay, bedensel bütünlüğü ihlâl edilen ev kadınının tazmin talebini, fark kuramı bağlamında malvarlığında bir eksilme olup olmadığını tartışmamakla birlikte kabul etmektedir. Aynı durum, emekliler açısından da geçerlidir. Burada da Yargıtay, halen bir işte çalışmayan ve ileride de çalışması mümkün olmayan emeklilerin tazmin talebini kabul ederek, çalışma gücünün kendisini (elde edilen karşılığı değil) bir malvarlığ 1 değeri olarak kabul ettiğini göstermektedir. Ulaşılan sonuç açısından bakıldığında Yargıtay'ın Alman ve İsviçre Hukuku'ndaki yargısal uygulamanın önünde olduğu söylenebilir.

\footnotetext{
${ }^{36}$ Yarg. 19. HD 03.10 .1995 T., $\quad$ E. 1076, K. 7783 [İlgili karar için bkz: http://www.turabitural.av.tr/html/kadin dosyalar/kadin3.htm (E. T.: 15.05.2006)]. Benzer şekilde Yargıtay 19. HD, 14 Ekim $1 \overline{993}$ tarihli kararı ile çalışma gücünü sürekli olarak kaybeden ev kadınının zararının saptanmasında, yaşam süresinin göz önüne alınması gerekeceğine, zira ev hizmetleri yönünden çalışma gücündeki kaybın yaşam süresince devam edeceğine hükmetmiştir. Yarg. 19. HD 14.10.1993 T., E. 605, K. 6582 (IBBD 2001/Eylül, S. 3, s. 939) [naklen: http://www.turabitural.av.tr/html/kadin_dosyalar/kadin3. htm (E. T.: 15.05.2006)

${ }^{37}$ Yarg. 11. HD 27.06.1996 T., E. 3356, K. 4735 (Eriş, G.: Kara Taşıma Hukuku, Ankara 1996 s. 722).

${ }^{38}$ Yarg. 4. HD 28.12.1998 T., E. 7858, K. 10906. [İlgili karar için bkz.: http://www.turabitural.av.tr/html/kadin_dosyalar/kadin3.htm (E. T.: 15.05.2006)]. Benzer sekilde Yargitay 4. HD 14 Subat 2002 tarihli kararı ile, davacının memur olması nedeniyle 65 yaşına kadar hesaplama yapılan bilirkişi raporunu kararına esas alan yerel mahkeme kararını, "davacı beden gücü kaybı nedeniyle pasif dönemde de daha fazla efor sarf ederek yaşamını sürdüreceğinden pasif dönemin de hesaplamada gözetilmesi gerekeceği" gerekçesi ile bozmuştur (Yarg. 4. HD 14.02.2002 T., E. 2001/10857, K. 2002/1844) [http://www.turabitural.av.tr/html/kadin_dosyalar/kadin3.htm (E. T.: 15.05.2006)].
} 


\section{SONUC}

Belirtildiği gibi, halen geçerli olan anlayıș bir maddî zararın varlığından bahsedilebilmesi için malvarlığında bir eksilmeyi koşul olarak aramaktadır. Malvarlığında eksilme, aktiflerin azalması ve pasiflerin artması (fiilî zarar) şeklinde olabileceği gibi, malvarlığındaki artışın engellenmesi (yoksun kalınan kazanç) şeklinde de olabilir. Ancak bu anlayış, Alman Hukuku'nda mutlak geçerliliğini kaybetmiş, örneğin bir eşyanın kullanma olanağından geçici olarak yoksun kalınmasında veya ev kadınının çalışma gücünü kaybetmesinde olduğu gibi, geleneksel anlamı ile malvarlı̆̆ında bir eksilme gerçekleşmeden de tazmin talebi kabul edilir hale gelmiştir. Bu kabul, malvarlıksal değerlerin kapsamının genişletilmesi ile ilgili bir sürecin sonucudur. Her ne kadar koruma altına alınan malvarlıksal değerler pozitif hukuk tarafindan belirlenmekte ise de, Alman Hukuku'nda yarg1 uygulaması ve öğreti piyasada bir karșılığı olan kazanç olanaklarını ve bir bedel ödenerek satın alınabilen kullanma olanaklarını da malvarlığının kapsamına dahil etmekte (ticarîleştirme düşüncesi) ve bu olanaklardan yoksun kalınması nedeniyle ortaya çıkan zararı da (normatif zarar) tazmin etmektedir.

Biz bu noktada bir adım daha ileri giderek çalışma gücünün kaybı söz konusu olduğunda, ev kadınında olduğu gibi, "ev işleri bir başkası tarafından yapılmış olsaydı bu kişiye bir karşılık ödenecekti” şeklinde bir varsayıma gerek olmadan tazminata karar verilebileceği düşüncesindeyiz. Bu, çalışma gücünün kendisinin bir malvarlığ 1 değeri olarak kabul edilmesi ve böylelikle bireyin sahip olduğu çalışabilme ve gelir elde edebilme olanağının mutlak olarak korunması anlamına gelmektedir. Aksine bir düşünce, bireyin kişisel gelişimine, yani özgürce kişiliğini geliştirebilme ve hareket edebilme olanaklarına zarar verir. Zira, çalışma gücünü kullanamayan, yani -soyut anlamda- bedensel ve zihinsel yeteneklerinden yararlanamayan birey, bir engellenme duygusu ile karşılaşır. $\mathrm{Bu}$ engellenme duygusu, sorumluluk hukukunun araçları ile ortadan kaldırılmak zorundadır.

$\mathrm{Bu}$ bakış açısı, ev kadınının olduğu kadar, emeklinin, işsizin ve öğrencinin bedensel bütünlüğü ihlâl edildiğinde de çalışma gücünün kaybı nedeniyle ortaya çıkan zararın tazminini sorunsuz hale getirecektir. Türk Hukuku'ndaki yargisal uygulama da bizim bu görüşümüzü destekler niteliktedir.

Elbette burada geleneksel anlamı ile fark kuramının dışına çıkıldığı ve kuramın, yargısal uygulamadan kaynaklanan bir istisnasının yaratıldığı göz ardı edilmemelidir. 


\section{KAYNAKÇA*}

AŞÇIOĞLU, Ç.: Trafik Kazalarında Hukukî Sorumluluk ve Tazminat Davaları, Ankara 1989.

BREHM, R.: Berner Kommentar, Schweizerisches Zivilgesetzbuch, Das Obligationenrecht, Bd. VI, 1. Abt. Allgemeine Bestimmungen, 3. Teilbd., 1. Unterteilbd. Die Entstehung durch unerlaubte Handlungen, Kommentar zu Art. 41-61 OR, 2. Aufl., Bern 1998.

BRINKER, J.: Die Dogmatik zum Vermögensschadensersatz, Berlin 1982.

DESCHENAUX, H./TERCIER, P.: Sorumluluk Hukuku (Çev. Özdemir, S.), Ankara 1983.

EREN, F.: Borçlar Hukuku Genel Hükümler, 8. B., İstanbul 2003.

ERIŞ, G.: Kara Taşıma Hukuku, Ankara 1996.

ERMAN/KUCKUK: Bürgerliches Gesetzbuch, 11. Aufl., Münster-Köln 2004.

ERMAN/SCHIEMANN, G.: Bürgerliches Gesetzbuch, 11. Aufl., Münster-Köln 2004.

FEYZİĞLU, F. N.: Borçlar Hukuku Genel Hükümler, C. I, 2. B., İstanbul 1976.

GAUCH, P.: Grenzüberschreitungen im privaten Schadensrecht, Richterliche Rechtsfortbildung in Theorie und Praxis, Festschrift für Hans Peter Walter, Bern 2005, s. 293-319.

GÖKYAYLA, K. E.: Destekten Yoksun Kalma Tazminatı, Ankara 2004.

GRUNSKY, W.: Aktuelle Probleme zum Begriff des Vermögensschadens, Berlin-Zürich 1968.

GRUNSKY, W.: Münchener Kommentar zum Bürgerlichen Gesetzbuch, München 1994 (MüKo/Grunsky).

HONSELL, H.: Schweizerisches Haftpflichtrecht, 3. Aufl., Zürich 2000.

JAUERNIG, O./TEICHMANN, A.: Bürgerliches Gesetzbuch, München 1997.

KARAKAŞ, F. T.: Eleştirel Bakış Açısıyla Normatif Zarar Kuramı, Ankara 2004 (yayımlanmamış doktora tezi).

KELLER, A.: Haftpflicht im Privatrecht, Bd. II, 2. Aufl., Bern 1998.

LANGE, H./SCHIEMANN, G.: Schadensersatz, 3. Aufl., Tübingen 2003.

LARENZ, K.: Lehrbuch des Schuldrechts, Bd. I, Allgemeiner Teil, 14. Aufl., München 1987.

MAGNUS, U.: Schaden und Ersatz, Tübingen 1987.

MAIER, G.: Schadensersatz bei Tötung oder Verletzung der im Haushalt tätigen oder im Beruf oder Geschäft des Mannes mitarbeitenden Ehefrau, Berlin 1976.

\footnotetext{
* Bir yazarın birden fazla eserine atıf yapılan durumlarda, eserleri birbirinden ayırmak için, parantez içinde eserin kısaltması verilmiştir.
} 
MEDICUS, D.: Normativer Schaden, JuS 1979, s. 233-239.

MEDICUS, D.: Schuldrecht, Allgemeiner Teil, 8. Aufl., München 1995 (Schuldrecht).

MERZ, H.: Schweizerisches Privatrecht, Bd. VI, Obligationenrecht, Allgemeiner Teil, Teilbd. 1, Basel-Frankfurt a. M. 1984.

NOMER, H.: Haksız Fiil Sorumluluğunda Maddî Tazminatın Belirlenmesi, İstanbul 1996.

OFTINGER, K.: Schweizerisches Haftpflichtrecht, Bd. I, Allgemeiner Teil, 4. Aufl., Zürich 1975.

OĞUZMAN, K./ÖZ, T.: Borçlar Hukuku Genel Hükümler, 4. B., İstanbul 2005.

PALANDT, O./HEINRICHS, H.: Bürgerliches Gesetzbuch, 62. Aufl., München 2003.

REY, H.: Ausservertragliches Haftpflichtrecht, Zürich 1995.

ROBERTO, V.: Schadensrecht, Basel-Frankfurt a. M. 1997 (Schadensrecht).

ROBERTO, V.: Schweizerisches Haftpflichtrecht, Zürich 2002 (Haftpflichtrecht).

SCHIEMANN, G.: Argumente und Prinzipien bei der Fortbildung des Schadensrechts, München 1981.

SCHWENZER, I.: Schweizerisches Obligationenrecht, Allgemeiner Teil, 2. Aufl., Bern 2000.

SOERGEL, H. T./MERTENS, H. J.: Bürgerliches Gesetzbuch, Stuttgart 1990.

STOLL, H.: Begriff und Grenzen des Vermögensschadens, Karlsruhe 1973.

TANDOĞAN, H.: Türk Mes'uliyet Hukuku, Ankara 1961.

TEKINAY, S. S./AKMAN, S./BURCUOĞLU, H./ALTOP, A.: Borçlar Hukuku Genel Hükümler, 7. B., İstanbul 1993.

von TUHR, A.: Borçlar Hukukunun Umumî Kısmı (Çev.: Edege, C.), C. 1-2, Ankara 1983.

TUNÇOMAĞ, K.: Borçlar Hukuku, C. I, Genel Hükümler, İstanbul 1972.

UYGUR, T.: Açıklamalı-İçtihatlı Borçlar Kanunu, Sorumluluk ve Tazminat Hukuku, C. II, Ankara 2003. 